\title{
Benefit Approach in Tax Collection for the State Welfare: A Comparative Analysis
}

\author{
Submitted 11/03/20, 1st revision 18/04/20, 2nd revision 28/05/20, accepted 30/07/20
}

\section{Sartono $^{1}$}

\begin{abstract}
:
Purpose: This study seeks to explore scientific fundamentals in tax collection. This approach is based on philosophical aspects which justify the state to collect taxes as collections that can be forced in the sense of having legal authority.

Approach/Methodology/Design: The benefit approach in withdrawing taxation is the philosophical basis for tax collection in Indonesia based on the benefit approach.

Findings: The benefit approach is based on the philosophy that the state creates benefits which can be enjoyed by all citizens who reside in the state. In Indonesia the taxation is based on Pancasila containing the nature of kinship and cooperation. Mutual cooperation is such a joint venture carried out without being rewarded aimed at the public interest. Based on Pancasila, tax collection can be justified because the tax payment is intended for the interests and the welfare of the people.

Practical Implications: This benefit approach bases a philosophy that because the state creates benefits that can be enjoyed by all citizens who live in the country, the state has the authority to collect taxes from the people even in a forced way.

Originality/value: This study conceptually combines taxation theories and their functions in state finance in a theoretical context of the benefit approach on the basis of kinship and mutualism inherent in Pancasila as justification for the use of taxes for the greatest prosperity of the people.
\end{abstract}

Keywords: Benefit approach, tax collection, economic principles, legal certainty, scientific fundamentals.

JEL code: $H 2$.

Paper Type: Research article.

\footnotetext{
${ }^{1}$ Universitas Pembangunan Nasional Veteran Jakarta, Pondok Labu, South Jakarta 12450 Indonesia, e-mail: sartono.jayabayajkt@gmail.com
} 


\section{Introduction}

Formally, the state is an organization of power incarnated in government (staatoverheid), while materially, it refers to the community life (staat-gemeenschap). To ensure the survival, the country must be financed from state income. One of the country's income comes from the people through taxation. Tax levies reduce individual income, but instead constitute state income which is then returned to the community through routine expenditure and development which ultimately returns to the entire community that benefits the people. Tax collection for a country depends very much on the conception of the country concerned, that is, it depends on the nature of the state, its authority and its objectives (Soemitro, 1991). Philosophically, there are several views about the nature of the state. The nature of the state is intended as a description of the nature of the state.

According to Logemann (2012), the state is essentially an organization of power which includes or unites groups of people who are then called nations (Soehino, 1980). The theory of justification for tax collection emerged since the 18th century, these theories are relative in nature, because they are based on worldviews, backgrounds that differ from time to time (Brotodihardjo, 2010). The widely known justification of collection theories are insurance theory, interest theory, absolute tax liability theory or devotion theory and buying style theory (Rochmat, 2011; Mirrlees, 1976; Logue and Avraham, 2002; Nightingale, 2002). The role of the taxpayers in fulfilling the tax payment obligations is certainly expected in accordance with the framework of the self-assessment system adopted in Indonesia, in the tax laws since 1983. The selfassessment system has given full confidence to the taxpayer community to calculate, deposit, and report the taxes themselves. This study seeks to explore scientific fundamentals in tax collection by using benefit approach as scientific fundamental to explore the justification of tax for the greatest prosperity of people. This approach is a fundamental basis on the philosophical basis which justifies the state to carry out tax collection as a collection that can be forced in the sense of having authority with force to force.

\section{State and Taxation}

The state as an organization of power implies that in every state there will always be centers of power. Martosoewignjo (1996) said that the centers of power both contained in the supra political structure, as well as those contained in the political infrastructure. These power centers have power, meaning that they have the ability to impose their will on others, or the ability to influence and control others. State, according to Prodjodikoro (1977), is an organization among a group of people who jointly inhabit a certain area (teritoir) by recognizing a government that takes care of the order and safety of a group or several groups of people earlier. Isywara (1971) views the state in a formal and material sense. 
Jellinek (1912) looks at the state from two angles, namely the state as a community building (gesellschaftlicher gebilde), but in addition it is also a legal building or institution (rechtliche). As a form of social life, the state is a unity of community life (Von Bernstorff, 2012). The state is manifested in a large number of wills which are bound together as unanimity and directed towards certain goals which become common goals (Attamimi, 1990).

Juridically, the state appears as a state of law that can be seen in terms of its structure or structure based on legal provisions consisting of state institutions and organs. The state is a balance of power, a balance of power in society. Jellinek (2013) provides a definition of the state in his book "Allgenteine Staatslehre" as a unity of ties of people who reside in certain residences and are equipped with original power to govern (Prodjodikoro, 1977). State according to Maclver (1980) is an association which acting through law as promulgated by a government endowed to this end with coercive power maintain within a community territorially demarcated the external condition of order. The state is an association that organizes control in a community in an area based on a legal system organized by a government for which purpose is given coercive power.

\section{Scientific Fundamentals of Taxation}

According to insurance theory, the state is likened to an insurance company, whose duty is to protect people from all their interests, safety, security of life as well as property. As is the case with an insurance agreement, protection is required to pay premiums. This tax is considered the premium. This insurance theory was eventually abandoned by people, because it was considered incompatible with the nature of taxes. In insurance, the insured party will immediately get compensation directly and the guarantor, if an event occurs as stated in the agreement. In taxes, there are no achievements that can be directly appointed to tax payments.

According to the theory of interests, the state imposes taxes on its people because the state has protected the interests of the people. The amount of tax is in accordance with the magnitude of the interests of protected taxpayers. The greater the protected interest, the greater the tax that must be paid. Many people who do not agree with this theory, because in reality it is the poor who ask for protection or service and the state. The consequence of this theory is that the poor must receive a greater tax burden than the rich. Herein lies the lameness of this theory, so that the same fate, left by people.

According to the theory of carrying capacity, every person is obliged to pay taxes according to their own bearing capacity. De Langen's endurance is the power of a person to carry a burden from what is left, after all his income has been reduced by absolute expenses for the primary needs of himself and his family (Rochmat, 2011). Cohen Stuart describes the ability of a person to bear as the strength of a bridge minus its own weight (Brotodihardjo, 2010). The opinions are basically the same, that the entire income of a person is identical to the entire bearing capacity of the bridge, while 
the principal expenditure is identical to the weight of the bridge. So someone's endurance is measured based on the rest of the total income obtained minus the absolute expenditure that must be spent (Rochmat, 2011). This criticism of the theory of bearing power is not actually a theory to provide justification for tax collection, but rather a basis for collecting fair tax.

Finally, the theory of absolute tax liability is also called the theory of devotion. This theory is based on the understanding of state organizations which demonstrate that the state as an organization has a duty to hold public interests. With the state's tasks, the state must take the necessary actions and decisions, including taxation actions and decisions. With such state organizations and actions, on the one hand the state has the absolute right to collect taxes, on the other hand the people must realize that the original obligation of the people to show their signs of service to the state is to pay taxes. With such absolute rights this theory is known as absolute obligation theory. On the other hand, because the people must show their sign of devotion by paying taxes in an obedient and disciplined manner, this theory is also called the theory of devotion. So according to this theory, the basis of tax law lies in the relationship between the people and the state. The state has the right to collect taxes, the people are obliged to pay taxes.

Theory of purchasing power presents that the implementation of community interests can be considered as the basis of fair tax collection, not individual interests and also not the interests of the state but the interests of the community which includes both. It can be argued that this theory emphasizes its teaching on the function of regulating (Rochmat, 2011). According to this theory, the tax function can be likened to a pump, which takes the purchasing power of individual households from the community to be included in a state household and then ejects it back from the state household to the community to achieve a common goal. So this theory does not pay attention to the origin of the state collecting taxes, but sees the influence or effect of tax collection and the good effect as a basis for justice. Soemitro (1991) provides a theory of tax justification according to Pancasila.

Pancasila contains the nature of kinship and cooperation. Mutual cooperation is a joint venture carried out without being rewarded aimed at the public interest or common interest. Kinship as the nature of Pancasila means, that every member of the community based on the nature of kinship, is obliged to help, maintain, sustain life, and maintain the good name of the state, by making sacrifices without any counterachievement compensation from the state. The nature of mutual cooperation is a joint venture in the public interest without being given or receiving special rewards. Based on Pancasila, tax collection can be justified because the tax payment is intended for the interests and welfare of the people.

\section{Economic Objectives and Legal Basis for Tax Collection}


The existence of taxes in the midst of society cannot be separated from the public interest. Where there is a public interest, a tax levy arises, so that the compound tax with the public interest. Therefore, the most basic consideration in the matter of tax collection is highly dependent on the conception adopted by the country concerned. This is included in the jurisdiction of state administration (Rochmat, 2011).

The state is an organization formed under public law. In accordance with its formation, the state has a public legal responsibility, which requires the state to pay attention to the public interest. Based on the rights of public law, the state in various ways can do something other than the subject of the private economy, namely the state is able to hold every possession of economic goods, forcing private households to surrender tenure rights without contra achievements such as taxes, as well as great power to create and order to create money for their interests in carrying out various actions in the public interest. Goedhart and Ratmoko (1982) categorizes tax as a special form of state income based on public law that is levied as forced collection without counterperformance.

In relation to taxes as a source of state revenue, the collection is the authority of the state, that is, the power to collect taxes from the people in accordance with applicable laws and regulations. Tax collection is a legal relationship between the state in its position as tax authorities with the people as tax payers. Thus the tax collection by the state to its people is within the scope of public law (Brotodihardjo, 2010). Countries that embrace the understanding of power (machtstaat) do not need a legal basis and tax principles, because for the country, law is what is desired and determined by the government. The state is seen as an instrument of power that is solely used to defend and defend the interests of the authorities. Therefore all means are halted for the achievement of objectives (Budiyanto, 2003).

According to Soemantri (1992) the most important elements of the rule of law are that the government in carrying out its duties and obligations must be based on a legal or statutory basis, with guarantees of human rights of citizens, and the distribution of power within the State, as well as oversight of judicial bodies (rechielijke controle). The two views above provide a clue that the universal characteristic of the rule of law concept, whatever the type of rule of law (rechtsstaat) adopted is the application of the principle of legality, the principle that requires that every state and people's actions must be based on applicable regulations. The concept of the rule of law began to develop rapidly since the end of the 19th century and the beginning of the 20th century (Marbun, 2011).

In the 19th century, Continental European countries adopted a formal legal state or rule of law in an anti-narrow state which is also called a night watchman state (nachwakerstaat), a country where everything is based on written law that is realized in the form of a law. The role of the state in this matter is only to make and maintain laws to ensure order, security and order, while other matters are left entirely to the citizens. In line with the times, along with the increasing demands of life's necessities, 
the role of the state becomes indispensable to meeting the needs and welfare of its citizens. Therefore the concept of formal rule of law began to be abandoned and entered the 20th century the concept of material rule of law or the concept of rule of law in a broad sense began to be developed. The role of the state in the material law state is getting bigger and wider, namely organizing public welfare called welfare state (Esping-Andersen et al., 2002; Kumlin and Rothstein, 2005).

The development of the concept of the rule of law has an influence on state activities in various fields including tax collection. In a state law, tax collection carried out by the state against the people, in addition to being based on laws and regulations, also gives an obligation to the state to carry out people's welfare. Tax collection as such power is in the hands of the state, even the rule of law can be created by the state itself (Nurchalis, 2018). Therefore it must be accompanied by devotion to the people, to the general welfare, so that it is transformed into justice. The state is justified in collecting taxes, but to achieve justice must be balanced with the obligation to raise the welfare of the general public (Djajadiningrat, 1965).

The legal state of Indonesia is a state based on Pancasila, a prosperous state based on law based on Pancasila, both as the basis of the state and as a source of all sources, by rejecting absolutism (Basah, 1985). In a state based on Pancasila, the state is obliged to organize social welfare by carrying out national development. National development can be carried out as planned if it is supported by the availability of large and sufficient funds. One of the sectors chosen and relied on by the government as a source of funding for development financing is taxes. Article 23A of the 1945 Constitution stipulates that taxes and other levies that are coercive for the purposes of the state are regulated by law, constituting the legal basis for every tax levy in Indonesia. This provision is a form of the principle of legality as one element of the rule of law, namely that tax collection by the state must be based on law.

Therefore, it is not possible to formally levy a formal juridical tax if it is not based on law. Tax law is part of public law, which is the overall norm governing the relationship between the government as tax authorities and the people as tax payers. The tax law contains the provisions that are material and the provisions that are formal. Material provisions are rules that contain subjects, objects and tariffs that absolutely must be regulated in the form of laws, are not allowed to be contained in regulations that are lower than the law, as well as changes. Another case with formal provisions, namely the provisions governing the implementation of material provisions. Such provisions are not absolutely required to be contained in the form of a law but can also be regulated by regulations that are lower than the law (Rochmat, 2011).

The provisions of Article 23A of the 1945 Constitution, although they constitute the legal basis for taxation, are essentially implied by the philosophy of taxation. Tax is a transfer of wealth and people to the government, without any compensation that can be directly appointed. So that the tax is not said to be robbery or a gift, it is required to have to get the approval of the people in advance considering the tax collection will 
burden all the people. The people's approval was obtained through their representatives in the House of Representatives, when the Draft Law was discussed. When the Tax Bill has been approved by the House of Representatives, it means that it has received approval from the people. This mechanism is in accordance with the provisions of Article 5 paragraph (1) and Article 20 paragraph (1), paragraph (2) and paragraph (4), the 1945 Constitution, which requires that every statutory regulation in the form of a law be a product cooperation between the House of Representatives and the President.

The tax philosophy implied in Article 23A, the 1945 Constitution, is coincidentally the same as in developed countries, "no taxation without representation" is a tax philosophy in Britain, whereas in the United States it is said "taxation without representation is robbery" (Dorfman, 2007). This tax philosophy contains the core of the recognition and appreciation of democratic institutions as a manifestation and understanding of people's sovereignty, namely human rights incarnated in the principle of popular sovereignty through their representatives in parliament in the form of determining the existence of tax collection.

In the provisions of Article 23A of the 1945 Constitution, it is also emphasized that the right to collect taxes is the state. State implementation of collecting taxes is carried out by the government as the organizer of state organizations, both the Central Government and Regional Governments. Not all elements of the government as public authorities have the authority to carry out tax collection, which is authorized only certain agencies and officials who are appointed by law. The authority to collect taxes can be delegated by appointing private persons or private entities in accordance with the law. A private person or private entity has the position of withholding or collecting income taxes in accordance with a tax collection system called the withholding system (Tax Counseling Center, 1991; Marsyahrul, 2005), a system that gives authority and trust and responsibility to taxpayers whose status is a tax deduction, or collectors of income tax, especially for Income Tax, Article 21, Article 22, Article 23 and 26 of Law No. 17 of 2000 concerning Income Taxes. In addition, it also gives authority and trust and responsibility to taxpayers to collect Value Added Tax according to Law of 18 of 2000 concerning Value Added Tax and Sales Tax on Luxury Goods. The transfer of authority is solely for calculating, deducting and the obligation to deposit tax payable (Manan, 1995).

\section{Conclusion}

Based on the rights of public law, the state in many ways can do something other than the subject of the private economy, namely the state is able to hold every possession of economic goods, forcing private households to surrender tenure rights without contra achievements such as taxes, as well as great power to create and order to create money for their interests in carrying out various actions in the public interest. 
Countries that have the right to levy on all income taxpayers based on the residence of the taxpayer. Taxpayers residing in Indonesia are taxed on income received or obtained, originating from Indonesia or from abroad. Secondly, the principle of nationality is the imposition of taxes related to a country. This principle is applied to every foreigner who resides in Indonesia to pay taxes. The benefit approach in withdrawing taxation is the philosophical basis for tax collection in Indonesia based on the benefit approach. The benefit approach is based on the philosophy that because the state creates benefits that can be enjoyed by all citizens who reside in the state, the state has the authority to collect taxes from the people in a forceful manner. Pancasila contains the nature of kinship and cooperation. Mutual cooperation is a joint venture carried out without being rewarded aimed at the public interest or common interes. Based on Pancasila, tax collection can be justified because the tax payment is intended for the interests and welfare of the people.

From the collection model, even though the tax calculation is done by the taxpayer himself based on a self-assessment system, this does not mean that fiscus (tax officer/official) is not authorized to conduct an examination by correcting and recalculating and subsequently self-determining the tax due. Based on this condition, where taxpayers often object to the determination of the amount of tax owed by the fiscus as outlined in the tax collection Letter, a dispute will arise between the taxpayer and the tax authorities. The relationship between the state and state finances and its relation to tax according to the conception of the state, has provided clarity that the implementation of the nature of the state as an organization of power is reflected in its characteristics, including the right to collect taxes on its people. The state's authority to collect taxes is based on its power as a sovereign state that has public rights so that tax collection rights become a state monopoly. In relation to taxes as a source of state revenue, the collection is the authority of the state, that is, the power to collect taxes from the people in accordance with applicable laws and regulations. Tax collection is a legal relationship between the state in its position as tax authorities with the people as tax payers.

\section{References:}

Attamimi, A.H.S. 1990. The role of the president's decision of the Republic of Indonesia in the administration of state government: an analytical study of the presidential decree which functions as a regulator in the period of Pelita I-Pelita IV.

Basah, S. 1985. The existence and benchmarks of the administrative justice body in Indonesia. Bandung, Alumni.

Brotodihardjo, R.S. 2010. Introduction to Tax Law. Bandung, Refika Aditama.

Budiyanto, B. 2003. Fundamentals of State Administration. Jakarta, Gelora Aksara Pratama.

Djajadiningrat, S.I. 1965. Tax Law and Justice. Bandung, Eresco.

Dorfman, G. 2007. The Founders' Legal Case: No Taxation without Representation versus Taxation No Tyranny. Hous. L. Rev., 44, 1377.

Esping-Andersen, G., Gallie, D., Hemerijck, A., Myles, J. 2002. Why we need a new welfare state. OUP Oxford.

Goedhart, C., Ratmoko. 1982. An outline of state finance. Jakarta, Djambatan. 
Ilyas, B. and Richard Burton 2008. Tax law. Jakarta, Djambatan.

Isywara, I. 1971. Pengantar Ilmu Politik. Bandung, Bina Cipta.

Jellinek, G., Jellinek, W. 2013. Allgemeine Staatslehre: Manuldruck. Springer-Verlag.

Kumlin, S., Rothstein, B. 2005. Making and breaking social capital: The impact of welfarestate institutions. Comparative political studies, 38(4), 339-365.

Logemann, J.L. 2012. Trams Or Tailfins? Public and Private Prosperity in Postwar West Germany and the United States. University of Chicago Press.

Logue, K., Avraham, R. 2002. Redistribution Optimally: Of Tax Rules, Legal Rules, and Insurance. Tax L. Rev., 56, 157.

MacIver, R.M. 1980. The Modern State. London, Oxford University.

Manan, B. 1995. Judicial Power of the Republic of Indonesia. Bandung, Bandung Islamic University.

Marbun, S.F. 2011. State administrative justice and administrative efforts in Indonesia. FH UII Press.

Marsyahrul, T. 2005. Withholding and Collection Income Tax Article 21, 22, 23, 26 of Law No. 17/2000. Jakarta, Grasindo.

Martosoewignjo, S.S. 1996. The function of the Constitution in Limiting Power. Ius Quia Iustum, 3(6), 1-6.

Mirrlees, J.A., 1976. Optimal tax theory: A synthesis. Journal of Public Economics, 6(4), $327-$ 358.

Nightingale, K. 2002. Taxation: Theory and practice. Pearson education.

Nurchalis, N. 2018. The Effectiveness of Criminal Sanction on the General Provisions of Taxation in Addressing Corporation Tax Evasion. Jurnal Hukum dan Peradilan, 7(1), 2344.

Prodjodikoro, R.W. 1977. Principles of Constitutional Law in Indonesia. Bandung, Eresco.

Rochmat, S. 2011. Principles and Basis of Taxation. Bandung, Eresco.

Soehino, S. 1980. State science. Jakarta, Liberty.

Soemantri, S. 1992. Indonesian Constitutional Law. Bandung, Alumni.

Soemitro, R. 1991. Principles of Tax Law. Bandung, Binacipta.

Tax Counseling Center. 1991. Guide to Tax Counseling Material. Jakarta, Directorate General of Tax, Ministry of Finance.

Von Bernstorff, J. 2012. Georg Jellinek and the Origins of Liberal Constitutionalism in International Law. Goettingen J. Int'l L., 4, 659. 